\title{
Students' Attitudes towards the Effectiveness of Moodle Platform at Preclinical-Medical Level in PBL Curriculum
}

\author{
Teeranai Peerapolchaikul ${ }^{1}$, Nuchanart Suealek $^{2}$, Panadda Rojpibulstit $^{2}$ \\ 1 Medical student, Faculty of Medicine, Thammasat University, Pathum Thani, Thailand \\ 2 Department of Preclinical Sciences, Faculty of Medicine, Thammasat University, \\ Pathum Thani, Thailand
}

\begin{abstract}
Moodle is applied as an online learning management system in the Faculty of Medicine, Thammasat University (TU), where the curriculum has been based on problem-based learning (PBL) since 2015. Little research on the effectiveness of Moodle and students' attitudes during their studies at the preclinical medical level within a PBL curriculum has been conducted. Hence, this cross-sectional study focuses on second- and the third-year (MD-2 and MD-3) preclinical medical students' attitudes towards Moodle and its effectiveness in the PBL curriculum by using a 27-itemed self-constructed online questionnaire. Additionally, students' preferences as regards the materials managed by the Moodle platform were also evaluated as students' preferred behaving style (SPBS). After obtaining ethical approval from the Human Ethics Committee of TU No. 1 (Faculty of Medicine), the data was collected and analyzed by medians and inter-quartile ranges, Mann-Whitney U test, and Spearman correlation $(\rho)$. After analyzing the data, the results indicated the following: (1) the top four attitudes scores, (2) the two lowest-attitude scores, (3) the top five effectiveness scores (Ef), (4) the three lowest effectiveness scores, and (5) the top three SPBS scores. Interestingly, a stronger positive Spearman's correlation $(\rho)$ between 'Prefer doing quizzes in Moodle to in classroom' and 'Moodle enhances learning capability' was found for MD-3 compared with MD-2. This study reports that Moodle is preferable as a platform supporting students' self-learning within a PBL curriculum. However, to use the Moodle platform to the highest benefit, instructors need to upgrade its capabilities, especially in the area of student-teacher interaction and the enhancement of students' critical thinking and creativity, as demonstrated by the lowest scores obtained in this study.
\end{abstract}

\section{Introduction}

Teaching and learning through Internet platforms is very popular among instructors nowadays. This is not only due to the convenience and easy 
communication with learners but also because of the fact that the platforms offer a benefit in motivating learners to prepare the lesson beforehand and revise the learned contents, as well as to inquire about any problems with the instructors. Amongst the existing platforms, Moodle is globally one of the most popular open source ones. As a whole, the system is user friendly and capable of being both a content management system (CMS) and a learning management system (LMS) (Keengwe \& Agamba, 2012).

Through the Moodle platform, the LMS can help in teaching and learning in various aspects, including enabling teachers to provide students with materials of different types or real-time interaction with students. Moreover, it can be used as a learning resource for students, in many forms such as plain text, links, a source of references, or a repository for related documents. Moreover, Moodle can create activities that encourage learning, such as a forum (webboard), messaging, or chat, allowing students to exchange ideas, homework assignments, or quizzes, which enhance learners' understanding or enable students and teachers to communicate beyond the classroom. All of these activities encourage learners to be more enthusiastic about learning, including through preparation before entering the classroom. In addition, Moodle helps to promote teachers' activities across disciplines through their working together in order to share the responsibility for their students during the course (Schneider \& Binder, 2019). This is consistent with learning in modules or block systems, which normally integrate across disciplines both vertically and horizontally, as managed through the problem-based learning (PBL) model.

PBL is a student-centered teaching method in which learning results from the process of working towards the understanding or resolution of a problem. The problem, first encountered in the learning process, is normally designed based on the most common or relatively common real patients' problems. It is used to assist students in discovering their learning needs in order to solve the patient's problem in the scenario. After analyzing the process with peers in a group setting and researching it through the selfdirected learning (SDL) process, students conclude what they have learnt, supporting it with relevant information and evidence. The entire PBL process is under close observation by the facilitator. The main skill acquired from PBL, claimed to be key for medical students, is the SDL. In doing this, students gain integration of their knowledge related to the problem directly from their SDL, which develops the ability of literature-based inquiry necessary for acquiring lifelong learning skills (Sun et al., 2018). Based on this fact, to support medical students' self-learning and to encourage their active learning, the Faculty of Medicine, Thammasat University, where the medi- 
cal curriculum has been based on the PBL since its establishment, promotes using online learning platforms, such as Moodle as an LMS tool.

At present, the Moodle platform is applied in a variety of medical schools, such as the Pacific Northwest University of Health Sciences (Ye, 2015) and the Pakistani Medical Universities (Memon \& Rathore, 2018). They agree that Moodle is a convenient and effective LMS that delivers a powerful set of learner-centric tools and creates learning environments that encourage both teaching and learning. For this reason, LMS use is widespread, e.g. the Moodle platform, also in Thailand. Apart from this, its popularity result from their considerable benefits, i.e. they provide easy access to lesson contents via the Internet, which makes it 24-hour accessible without any limits in terms of lessons, locations, or times. Additionally, the key characteristics of learning through the Moodle platform that result in increased efficiency of teaching and learning are as follows: (1) learning efficacy through the 'anywhere, anytime' approach, (2) flexibility for supporting learners to access content on an as-needed basis. Moreover, due to its multimedia approach, the fact of the availability of various resources, such as web contents, videos, audios or files, can be communicated or shared; additionally, collaboration on tasks is possible throughout the course. This makes for a better class environment for collaborative learning and encouragement of discussion and interaction among students and teachers. In addition, Moodle also has a system that can measure and evaluate test results, with information passed on to learners immediately (Gamage et al., 2019), even in large group teaching sessions (Herbert et al., 2017). Lastly, Moodle is also an effective learning platform for teaching and learning within distance learning module systems (Półjanowicz et al., 2016).

Thammasat University (TU) has also been applying the Moodle platform as an LMS for five years at various courses. Subsequently, both clinical and preclinical level teachers at the Faculty of Medicine, TU, have been organizing courses via the Moodle platform with a variety of resources and activities, for example: teaching resources, various test materials, information on conference topics, sharing book recommendations, among others. Based on the massive contents in the field of medicine, using resources through the Moodle platform is not only beneficial for students due to the variety of tools capable of creating learning materials, but it also enhances the learning effectiveness through instructors' support. Moreover, posting the syllabi, assignments, teaching materials, course readings, etc., in Moodle reduces paper consumption and printing-related waste on campus in the move towards TU Green University. However, according to a systematic review of the effectiveness of Moodle at the preclinical-medical level of PBL curricula, related 
studies have been published (Kumar \& Shastri, 2017; Popovic et al., 2018). Therefore, a cross-sectional study was conducted in order to explore both the attitudes and the effectiveness of using Moodle in teaching and learning of second- and the third-year preclinical medical students at the Faculty of Medicine, TU. In addition, the preferred students' approach concerning Moodle (students' preferred behaving style, SPBS), such as the preference for taking every quiz in Moodle versus the preference for doing quizzes only in the classroom, was explored. The results might be helpful for Moodle instructors to improve its effectiveness in medicine in the $21^{\text {st }}$ century.

\section{Materials and Methods}

The research was conducted in second- and third-year preclinical medical students during the years 2017-2018. Every participant was allowed to access Moodle along the preclinical curriculum as shown in the example in Figure 1.

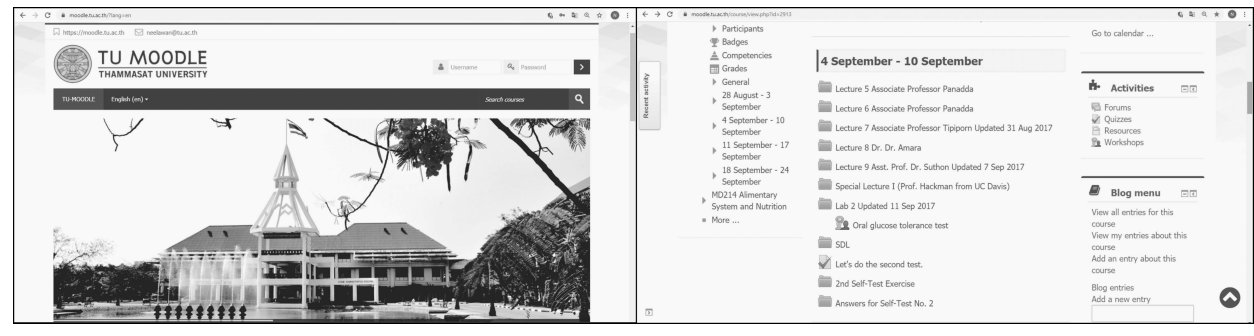

Figure 1. Left: screenshot of Moodle homepage (https://moodle.tu.ac.th/? lang=en); Right: screenshot of MD 314 Endocrine System of the 2017 curriculum (https://moodle.tu.ac.th/course/view.php?id=2913)

Questionnaire design: The study was conducted using a 27-item selfconstructed online questionnaire (five-point Likert scale ranging from one to five; 5: strongly agree; 4: agree; 3: have no idea; 2: disagree; 1: strongly disagree). Some of the questionnaires were adapted from studies by Marikar et al. (Marikar et al., 2016; Marikar \& Jayarathne, 2016), while the data analysis was based on the ordinal scale, i.e. using nonparametric instead of parametric tests. In the first part, the questionnaire begins with the demographic characteristics of the students, such as gender, year of study, and student performance (grade point average, GPA). The next part is designed to obtain information on (1) e-device usage for Moodle learning (via smartphone, notebook, tablet or PC), (2) network access points service (via campus-wide $\mathrm{Wi}-\mathrm{Fi}$, faculty-wide Wi-Fi, dormitory-wide $\mathrm{Wi}-\mathrm{Fi}$, or personal 
mobile data), and (3) a closed question as to whether Moodle is manageable as an e-learning source (yes/no response). The third part assesses personal attitudes, views on the effectiveness of Moodle, and students' preferences concerning Moodle-based activity (SPBS).

\section{Data analysis}

After obtaining the ethical approval by the Human Ethics Committee of TU No. 1 (Faculty of Medicine) (MTU-EC-SA-0-063/60), the data was collected and analyzed by medians and inter-quartile ranges (IQR) using the Statistical Package for the Social Sciences (SPSS). Mann-Whitney test was used for comparing the results between second- and the third-year students, while Spearman's correlation coefficient $(\rho)$ was used for the assessment of the relationships between the SPBS in Moodle and students' performance. Results at a level of $p<0.05$ were considered statistically significant.

\section{Results and Discussion}

Based on $86.60 \%$ response (291 out of 336 medical students), the demographic data showed that the response came from a higher percentage of second-year students (52.58\%) compared to third-year students (Table 1).

Table 1. Characteristics of respondents by academic level, gender, and performance

\begin{tabular}{|c|c|c|}
\hline \multicolumn{1}{|c|}{ Variable } & $\mathrm{N}$ & Percentage \\
\hline Year & & \\
$2^{\text {nd }}$ year students & 153 & 52.58 \\
$3^{\text {rd }}$ year students & 138 & 47.42 \\
\hline Gender & & \\
Female & 157 & 53.95 \\
Male & 134 & 46.05 \\
\hline Student performance (GPA) & & \\
GPA 2.00-2.49 & 14 & 4.81 \\
GPA 2.50-2.99 & 52 & 17.87 \\
GPA 3.00-3.49 & 122 & 41.92 \\
GPA 3.50-4.00 & 103 & 35.40 \\
\hline Total & 291 & 100 \\
\hline
\end{tabular}


This may stem from the fact that second-year students are fresher and more enthusiastic in providing useful feedback to develop better outcomes that they would benefit from in the next academic year, compared to third-year students, who mostly concentrate on their upcoming comprehensive and national license exams. In addition, the demographic data showed that the majority of responders were female (53.95\%), which may be due to the fact that most medical students enrolled at TU are female. This is strongly correlated with the report by the Washington-based Association of American Medical Colleges (Association of American Medical Colleges, 2017) which reports that the gender ratio of first-time applicants in medical schools in the United States tends towards female.

In addition, the data showed that most students access Moodle via portable devices such as tablets/iPads (52.36\%) and smartphones $(27.83 \%)$. Moreover, places such as home or dormitory tended to encourage students' learning and allowed them to access Moodle more frequently (30.53\%). Interestingly, the majority of students can easily manage Moodle (91.75\%), correlating with the fact that students of the generation in question grow up with technology and are more likely to learn how to use it faster than those who are not used to it as much (Figure 2).

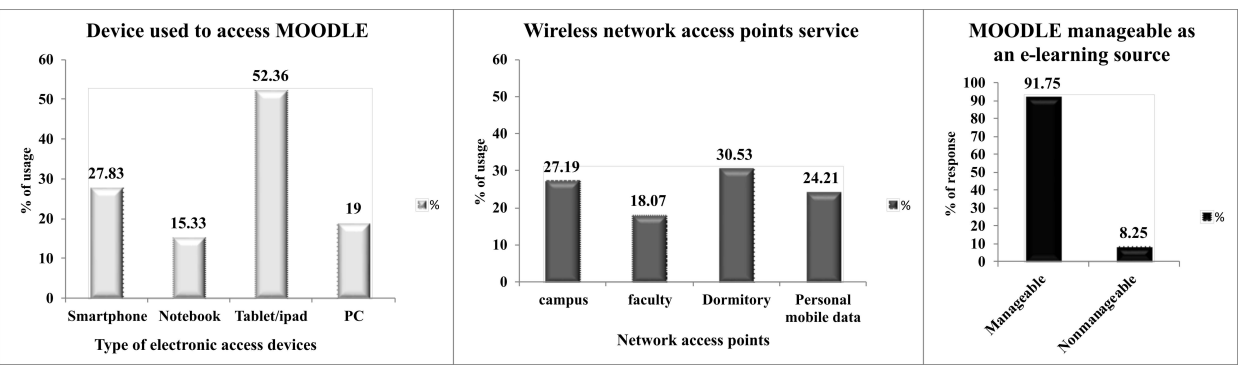

Figure 2. Students' responses on e-device usage for Moodle learning (left), network access points service (middle), and the closed question as to whether Moodle is manageable as an e-learning source (right)

Furthermore, the responses concerning students' attitudes towards Moodle showed that the top four attitudes were that Moodle helped the students to (1) be more comfortable (MD-2 $=4(4,5), \mathrm{MD}-3=4(4,5)$ ), (2) prepare themselves before class (MD-2 $=4(4,5), \mathrm{MD}-3=4(3,5))$, (3) enhance their learning capability (MD-2 $=4(4,5), \mathrm{MD}-3=4(4,5))$, and that (4) Moodle is an effective tool $(\mathrm{MD}-2=4(4,5), \mathrm{MD}-3=4(4,5))$, while the assistance of Moodle in classmate interaction and being an inconvenient learning tool were the two attitudes with the lowest scores. This supports the fact that the medical students at TU feel that Moodle benefits their 
Students' Attitudes towards the Effectiveness of Moodle Platform...

Table 2. Students' attitudes towards Moodle

\begin{tabular}{|l|c|c|c|c|c|}
\hline \multirow{2}{*}{ Question } & \multicolumn{2}{|c|}{$2^{\text {nd }}$ year } & \multicolumn{2}{c|}{$3^{\text {rd }}$ year } & $\begin{array}{c}\text { Mann Whitney } \\
\text { U test }\end{array}$ \\
\cline { 2 - 7 } & Median & IQR & Median & IQR & $p$-value \\
\hline $\begin{array}{l}\text { MOODLE helps student. To be more } \\
\text { comfortable }\end{array}$ & 4 & $(4,5)$ & 4 & $(4,5)$ & 0.487 \\
\hline $\begin{array}{l}\text { MOODLE helps student prepare } \\
\text { themselves before class }\end{array}$ & 4 & $(4,5)$ & 4 & $(3,5)$ & 0.208 \\
\hline MOODLE enhance learning capability & 4 & $(4,5)$ & 4 & $(4,5)$ & 0.232 \\
\hline MOODLE is an effective tools & 4 & $(4,5)$ & 4 & $(4,5)$ & 0.711 \\
\hline $\begin{array}{l}\text { MOODLE helps student interact with } \\
\text { classmate }\end{array}$ & 3 & $(2,4)$ & 3 & $(3,4)$ & 0.181 \\
\hline MOODLE is inconvenient & 2 & $(2,3)$ & 3 & $(2,4)$ & 0.055 \\
\hline Average value & 4 & $(3,4)$ & 4 & $(3,5)$ & 0.083 \\
\hline
\end{tabular}

learning (Table 2). Moreover, all of these are the main factors for encouraging students' active learning. This corresponds with principle 3 (Encourage active learning) of Chickering and Gamson's (1999) seven principle guidelines for good teaching practice. The aim of this guideline is to improve teaching and learning at the undergraduate level. However, active learning will not be successfully promoted if the handling of students' information and communication technology (ICT) is insufficient (Turner et al., 2017) or if teachers lack the necessary digital knowledge, as shown in a number of reports (Greene, 2018; Hatlevik \& Hatlevik, 2018; Howard \& Mozejko, 2015). As a consequence, as per the 21st century, providing a longer training with Moodle for both students and instructors could promote the benefits of using it. Lastly, an insignificant difference between second- and third-year students' attitudes towards Moodle test was shown using Mann-Whitney U (median score of attitudes for MD-2Att $=4(3,4)$, MD-3Att $=4(3,5)$, $p=0.083)$. This shows that, from students' viewpoint, Moodle steadily supports students' learning during the preclinical years.

Additionally, Table 3 presents the effectiveness of Moodle as perceived by the participants. Since third year medical students have one year's more familiarity with Moodle than second year students, who have just started to use it, the question is whether the more they use Moodle, the more effective the learning process. Hence, differences in attitudes concerning Moodle effectiveness among students at each year of study were compared. The top five effectiveness scores were as follows: (1) great quality of files uploaded (MD-2 $=4(4,5)$, MD-3 = $4(4,5))$, (2) adequate files for learn- 
Teeranai Peerapolchaikul, Nuchanart Suealek, Panadda Rojpibulstit

Table 3. Moodle effectiveness

\begin{tabular}{|l|c|c|c|c|c|}
\hline \multirow{2}{*}{\multicolumn{1}{|c|}{ Question }} & \multicolumn{2}{|c|}{$2^{\text {nd }}$ year } & \multicolumn{2}{c|}{$3^{\text {rd }}$ year } & $\begin{array}{c}\text { Mann Whitney } \\
\text { U test }\end{array}$ \\
\cline { 2 - 6 } & Median & IQR & Median & IQR & $p$-value \\
\hline Great quality of files uploaded & 4 & $(4,5)$ & 4 & $(4,5)$ & 0.536 \\
\hline Adequate files for learning & 4 & $(4,4)$ & 4 & $(3,4)$ & 0.467 \\
\hline $\begin{array}{l}\text { Well related lesson plan with course } \\
\text { outlines }\end{array}$ & 4 & $(4,4)$ & 4 & $(4,5)$ & 0.136 \\
\hline Easy communication & 4 & $(3,5)$ & 4 & $(4,5)$ & 0.294 \\
\hline $\begin{array}{l}\text { Well consistent learning activities } \\
\text { with course contents }\end{array}$ & 4 & $(3,4)$ & 4 & $(4,5)$ & 0.312 \\
\hline Well related with course periods & 4 & $(3,4)$ & 4 & $(3,5)$ & 0.275 \\
\hline Student center-based & 4 & $(3,4)$ & 4 & $(3,4.25)$ & 0.562 \\
\hline Encourages students' self-learning & 4 & $(3,4)$ & 4 & $(3,5)$ & $0.010^{*}$ \\
\hline Allows students to provide feedback & 4 & $(3,4)$ & 4 & $(3,5)$ & 0.711 \\
\hline Students' participation and interaction & 4 & $(3,4)$ & 4 & $(3,4)$ & 0.076 \\
\hline Enhances students' critical thinking & 4 & $(3,4)$ & 4 & $(3,4)$ & 0.091 \\
\hline Develops students' creativity & 3 & $(3,4)$ & 4 & $(3,4)$ & 0.053 \\
\hline Average value & 4 & $(3,4)$ & 4 & $(3,5)$ & 0.130 \\
\hline
\end{tabular}

ing (MD-2 $=4(4,4)$, MD-3 $=4(3,4))$, (3) lesson plan well related to course outlines (MD-2 $=4(4,4), \mathrm{MD}-3=4(4,5))$, (4) easy communication (MD-2 $=4(3,5)$, MD-3 $=4(4,5))$, and (5) learning activities consistent with course contents $(\mathrm{MD}-2=4(3,4), \mathrm{MD}-3=4(4,5))$. These results imply that Moodle has the potential not only for file management without decreasing their quality but also for flexibility in organizing course materials, thereby allowing instructors to communicate well with their students. These results support our successful blended learning model (Horvat et al., 2015) (i.e. mostly face-to-face lectures with online resources in classes at each academic year, as opposed to pure online learning), designed to maximize the benefits of the platform in facilitating student learning more effectively, rather than as a robust educational experience. Moreover, both secondand third-year students agreed that Moodle encouraged their self-learning (MD-2 $=4(3,4)$, MD-3 = $4(3,5))$; this finding correlates strongly with an educational study on students' satisfaction with the Moodle platform (Manzanares et al., 2019). This also aligns with Moodle's educational philosophy (Moodle, 2012) in that when used appropriately, the platform can facilitate SDL. From this perspective, not only does it serve the curriculum, 
but it also fits the PBL character of our medical curriculum. As is known, PBL is a well-recognized form of medical curricula worldwide, one that encourages students to experience life-long learning through the development of SDL skills (Bodagh et al., 2017; Loyens et al., 2008; Malan et al., 2014; Murad et al., 2010). Improved student capacity for dynamic independent learning through the Moodle platform, as exemplified by our medical school, may result in more competitiveness upon graduation, thus reducing the risk of patients receiving poor quality medical care (Marzo, 2018).

Remarkably, the three lowest scores were 'Students' participation and interaction', 'Enhances students' critical thinking', and 'Develops students' creativity'. These results were very surprising as Moodle is equipped with many features to support students' participation/interaction, such as through interactive quizzes providing students with feedback after they finish them or through a live chat between students, which could allow them to share their thoughts, with the instructor observing and giving feedback. Both of these tools have been found to increase problem-solving and collaboration skills (Lazakidou \& Retalis, 2010; Turner \& Leydon, 2012) as well as critical thinking skills (Meredith, 2014). Moreover, it was also found that developing students' creativity through Moodle during the surveyed period was placed at the bottom of the ranking. All of these might stem from the fact that even though Moodle has various features, it still depends on instructors to adapt and utilize those tools as well as on the proper design of learning and teaching (Songkram, 2017), such as through the use of project-based activity (Sompong, 2018). In addition, when comparing the effectiveness of Moodle between second- and the third-year students (Table 3), an insignificant difference between MD-3 and MD-2 was also found in respect to median (IQR) scores $(\mathrm{MD}-2 \mathrm{Ef}=4(3,4), \mathrm{MD}-3 \mathrm{Ef}=4(3,5)$, $p=0.130$ ), which correlates with the study of Półjanowicz et al. (2013) This result shows that students using Moodle for a longer period of time may perceive a greater benefits from using it.

Apart from students' attitudes towards Moodle and its effectiveness, Table 4 presents the results of SPBS concerning Moodle. Interestingly, the top three scores, both for second- and third-year students, are as follows: 'Prefer using Moodle to download learning files', which supports the result presented in Table 3, i.e. that Moodle is an excellent tool for file management and organizing course materials as well as keeping the files in good quality so that students can access learning contents more easily; 'Prefer doing multiple choice questions (MCQs) to essays', possibly because MCQs are easier to use when evaluating knowledge. It was found that assigning quizzes through an online course helps to assess learner's knowledge and provide feedback, 
Table 4. SPBS in Moodle

\begin{tabular}{|l|c|c|c|c|c|}
\hline \multirow{2}{*}{ Question } & \multicolumn{2}{|c|}{$2^{\text {nd }}$ year } & \multicolumn{2}{c|}{$3^{\text {rd }}$ year } & $\begin{array}{c}\text { Mann Whitney } \\
\text { U test }\end{array}$ \\
\cline { 2 - 6 } & Median & IQR & Median & IQR & $p$-value \\
\hline $\begin{array}{l}\text { Prefer using Moodle to download } \\
\text { learning files }\end{array}$ & 5 & $(5,5)$ & 5 & $(5,5)$ & 0.665 \\
\hline $\begin{array}{l}\text { Prefer doing multiple choice questions } \\
\text { (MCQs) to constructed response } \\
\text { questions (CRQs) }\end{array}$ & 4 & $(4,5)$ & 4 & $(4,5)$ & 0.497 \\
\hline Prefer full concentration in lectures & 4 & $(4,5)$ & 4 & $(4,5)$ & 0.003 \\
\hline Prefer doing every quiz in Moodle & 4 & $(3,5)$ & 4 & $(3,5)$ & 0.668 \\
\hline Prefer group discussion & 4 & $(3,4)$ & 4 & $(3,4)$ & 0.930 \\
\hline Prefer self-study & 4 & $(3,4.5)$ & 4 & $(3,5)$ & 0.169 \\
\hline $\begin{array}{l}\text { Prefer doing quizzes in Moodle to } \\
\text { in classroom }\end{array}$ & 4 & $(3,4)$ & 4 & $(3,5)$ & 0.112 \\
\hline $\begin{array}{l}\text { Prefer sending questions through } \\
\text { Moodle }\end{array}$ & 3 & $(2,4)$ & 3 & $(2.75,4)$ & 0.986 \\
\hline $\begin{array}{l}\text { Prefer to exchange ideas with other } \\
\text { students via Moodle platform }\end{array}$ & 3 & $(3,4)$ & 3 & $(3,4)$ & 0.862 \\
\hline Average value & 4 & $(3,5)$ & 4 & $(3,5)$ & 0.079 \\
\hline
\end{tabular}

assisting them in creating their own learning path (Chauhan \& Goel, 2016); and 'Prefer full concentration on lectures', reflecting a characteristic of medical students in that they have to collect as much information from the lectures as possible before self-studying at home. The data also shows the two lowest scores to be 'Prefer sending questions through Moodle' and 'Prefer to exchange ideas with other students via Moodle platform', both of which reflect the disadvantage of Moodle in the area of communication among students and instructors in that even though Moodle has various features that support the communication, it depends on instructors to applied those tools to enhance communication.

Interestingly, a more positive correlation between 'Prefer doing quizzes in Moodle to in classroom' and 'Moodle enhances learning capability' was found for second-year students in comparison with third-year students $(\rho \mathrm{MD}-3=+0.496, \rho \mathrm{MD}-2=+0.253, p<0.005)$ (Table 5, left $).$ It is surprising, however, that no correlation between students' active involvement in doing quizzes in Moodle with students' performance was found (Table 5, right). This might be because of the fact that all quizzes are self-scored and unmarked, solely for formative practices/exam preparation, not included 
Students' Attitudes towards the Effectiveness of Moodle Platform...

Table 5. Relationship between the preference for doing quizzes in Moodle and Moodle's enhancement of learning capability (left); and between doing every quiz in Moodle and academic performance (right)

\begin{tabular}{|c|c|c|c|c|c|c|c|}
\hline & \multicolumn{2}{|c|}{$\begin{array}{l}\text { Moodle enhances } \\
\text { learning capability }\end{array}$} & & & \multicolumn{2}{|c|}{$\begin{array}{c}\text { Academic } \\
\text { performance }\end{array}$} \\
\hline & & $2^{\text {nd }}$ year & $3^{\text {rd }}$ year & & & $2^{\text {nd }}$ year & $3^{\text {rd }}$ year \\
\hline \multirow{3}{*}{$\begin{array}{l}\text { Prefer do- } \\
\text { ing quizzes } \\
\text { in Moodle } \\
\text { to in class- } \\
\text { room }\end{array}$} & $\begin{array}{l}\text { Spearman } \\
\text { correlation }\end{array}$ & 0.253 & 0.496 & \multirow{3}{*}{$\begin{array}{l}\text { Doing } \\
\text { every quiz } \\
\text { in Moodle }\end{array}$} & $\begin{array}{l}\text { Spearman } \\
\text { Correlation }\end{array}$ & 0.075 & 0.118 \\
\hline & Sig. (2-tailed) & 0.002 & 0.000 & & Sig. (2-tailed) & 0.355 & 0.169 \\
\hline & $\mathrm{N}$ & 153 & 138 & & $\mathrm{~N}$ & 153 & 138 \\
\hline
\end{tabular}

as part of any final grade (Moore \& Iida, 2010). This also correlates with Sajid (Sajid et al., 2016), in that blended learning and flipped classroom are helpful in exam preparation and concept clarification, but no significant increase in students' academic performance was found. On the other hand, this constitutes a limitation of this study as participants' self-test scores were not corrected and compared with their performance. If they had been collected, this would have been beneficial in interpreting the results in order to improve e-learning materials for better academic achievements.

\section{Conclusion}

This paper reports that Moodle is preferable as a platform to support students' learning in PBL curricula. It consists of various effective tools that could be utilized to create learning contents. These tools could help instructors conduct their lectures more effectively. However, instructors need to upgrade the abilities of Moodle, especially in the low-scoring aspects. A systematic plan for improving Moodle's capability such as student feedback or a Moodle training programme for instructors should be initiated. Furthermore, for the highest benefit for the current generation of students, Moodle's capability would be more effective if instructors utilized it to generate interactive classes or flipped classes, which would challenge students' critical thinking and teamwork skills.

\section{Acknowledgements}

Involvement of all the participants, i.e. second- and the third-year medical students at TU (MEDTU25-26) is greatly appreciated. The authors would also like to show their gratitude to Assist. Prof. Dr. Piyanart 
Chatiketu for her special support in the area of statistical analysis. The authors acknowledge the support of the Faculty of Medicine, TU, and the Japan Society of Medical Education (JSME) in the form of an international travelling grant, which enabled the authors to attend the $50^{\text {th }}$ Annual Meeting of the Japan Society for Medical Education, 2017.

\section{R E F E R E N C E S}

Association of American Medical Colleges. (2017). Applicant and Matriculant Data Tables (pp. 1-9).

Bodagh, N., Bloomfield, J., Birch, P., \& Ricketts, W. (2017). Problem-based learning: a review. British Journal of Hospital Medicine, 78(11), C167-C170. doi: 10.12968/hmed.2017.78.11.C167

Chauhan, J., \& Goel, A. (2016). An analysis of quiz in MOOC. Paper presented at the Ninth International Conference on Contemporary Computing (IC32016), Noida, India.

Chickering, A. W., \& Gamson, Z. F. (1999). Development and adaptations of the seven principles for good practice in undergraduate education. New Directions for Teaching and Learning, (80), 75-81.

Gamage, S. H. P. W., Ayres, J. R., Behrend, M. B., \& Smith, E. J. (2019). Optimising Moodle quizzes for online assessments. International Journal of Stem Education, 6(1). doi: 10.1186/s40594-019-0181-4

Greene, K. (2018). "Transferable Digital Literacy Knowledge", The Language and Literacy Spectrum. 28(1), Article 3.

Hatlevik, I. K. R., \& Hatlevik, O. E. (2018). Examining the Relationship Between Teachers' ICT Self-Efficacy for Educational Purposes, Collegial Collaboration, Lack of Facilitation and the Use of ICT in Teaching Practice. Frontiers in Psychology, 9. doi: 10.3389/Fpsyg.2018.00935

Herbert, C., Velan, G. M., Pryor, W. M., \& Kumar, R. K. (2017). A model for the use of blended learning in large group teaching sessions. Bmc Medical Education, 1\%. doi: 10.1186/S12909-017-1057-2

Horvat, A., Dobrota, M., Krsmanovic, M., \& Cudanov, M. (2015). Student perception of Moodle learning management system: a satisfaction and significance analysis. Interactive Learning Environments, 23(4), 515-527. doi: $10.1080 / 10494820.2013 .788033$

Howard, S. K., \& Mozejko, A. (2015). Teachers: technology, change and resistance. In M. Henderson 8$\}$ G. Romeo (Eds.), Teaching and Digital Technologies: Big Issues and Critical Questions. Port Melbourne, Australia: Cambridge University Press.

Keengwe, J., \& Agamba, J. J. (2012). Course management systems integration into course instruction. International Journal of Information and Communication Technology Education, 8(2), 72-80. 
Kumar. B, S., \& Shastri, D. (2017). Effectiveness of Moodle on E-Learning Platform in Medical Education - A Review. National Journal of Basic Medical Sciences, 7(4), 251-260.

Lazakidou, G., \& Retalis, S. (2010). Using computer supported collaborative learning strategies for helping students acquire self-regulated problemsolving skills in mathematics. Computers \& Education, 54(1), 3-13. doi: 10.1016/j.compedu.2009.02.020

Loyens, S., Magda, J., \& Rikers, R. (2008). Self-directed learning in problem-based learning and its relationships with self-regulated learning. Educational Psychology Review, 20(4), 411-427. doi: 10.1007/s10648-008-9082-7

Malan, S. B., Ndlovu, M., \& Engelbrecht, P. (2014). Introducing problem-based learning (PBL) into a foundation programme to develop self-directed learning skills. South African Journal of Education, 34(1).

Manzanares, M. C. S., Garcia-Osorio, C. I., \& Diez-Pastor, J. F. (2019). Differential efficacy of the resources used in B-learning environments. Psicothema, 31(2), 170-178. doi: 10.7334/psicothema2018.330

Marikar, F. M., Alwis, K., Satharasinghe, S., Wickramasinghe, D., \& Kariyawasam, K. (2016). Moodle's effectiveness in a developing country. The Online Journal of Distance Education and e-Learning, 4(3), 66-76.

Marikar, F. M., \& Jayarathne, N. (2016). Effectiveness of Moodle in education system in Sri Lankan University. International Journal of Modern Education and Computer Science, 8(2), 54-58. doi: 10.5815/ijmecs.2016.02.07

Marzo, R. R. (2018). Role of medical education in cultivating lifelong learning skills for future doctors. Education in Medicine Journal, 10(3), 63-66. doi: 10.21315/eimj2018.10.3.7

Memon, A. R., \& Rathore, F. A. (2018). Moodle and Online Learning in Pakistani Medical Universities: An opportunity worth exploring in higher education and research. Journal of the Pakistan Medical Association, 68(7), 1076-1078.

Meredith, M. (2014). Testing the effectiveness of different Moodle assignment styles on improving student comprehension of biology concepts and attitudes toward homework assignments. (A professional paper submitted in partial fulfillment of the requirements for the degree of Masters of Science in Science Education), Montana State University, Bozeman, Montana. Retrieved from https://scholarworks.montana.edu/xmlui/bitstream/handle/1/3578/Meredi thM0814.pdf? sequence $=1 \&$ is Allowed $=y$

Moodle. (2012). Moodle philosophy. Retrieved from http://docs.moodle.org/22/en/ Philosophy

Moore, K., \& Iida, S. (2010). Students' perception of supplementary, online activities for Japanese language learning: Groupwork, quiz and discussion tools. Australasian Journal of Educational Technology, 26(7), 966-979. 
Murad, M. H., Coto-Yglesias, F., Varkey, P., Prokop, L. J., \& Murad, A. L. (2010). The effectiveness of self-directed learning in health professions education: a systematic review. Medical Education, 44(11), 1057-1068. doi: 10.1111/ j.1365-2923.2010.03750.x

Półjanowicz, W., Latosiewicz, R., Kołodziejczak, B., \& Roszak, M. (2016). Elearning for Part-Time Medical Studies. Studies in Logic, Grammar and Rhetoric, 47(1), 129-142. doi: 10.1515/slgr-2016-0051

Półjanowicz, W., Mrugacz, G., Szumiński, M., Latosiewicz, R., BakunowiczŁazarczyk, A., Bryl, A., \& Mrugacz, M. (2013). Assessment of the effectiveness of medical education on the Moodle e-learning platform. Studies in Logic, Grammar and Rhetoric, 35(1), 203-214. doi: 10.2478/slgr-2013-0037

Popovic, N., Popovic, T., Dragovic, I. R., \& Cmiljanic, O. (2018). A Moodle-based blended learning solution for physiology education in Montenegro: a case study. Advances in Physiology Education, 42(1), 111-117. doi: 10.1152/advan.00155.2017

Sajid, M. R., Laheji, A. F., Abothenain, F., Salam, Y., AlJayar, D., \& Obeidat, A. (2016). Can blended learning and the flipped classroom improve student learning and satisfaction in Saudi Arabia? International journal of medical education, 7, 281-285. doi: 10.5116/ijme.57a7.83d4

Schneider, M., \& Binder, T. (2019). E-Learning in medicine: Current status and future developments. Hamdan Medical Journal, 12(4), 147. doi: 10.4103/hmj. hmj_74_19

Sompong, N. (2018). Learning management system for creative thinking skill development with collaborative learning of the graduate students in Kasetsart University. International Journal of Environmental $\& 3$ Science Education, 13(6), 527-532.

Songkram, N. (2017). Online course design for creativity and innovative skills in virtual cultural ASEAN community: From research to empirical practice. International Journal of Emerging Technologies in Learning, 12(01), 4-20. doi: 10.3991/ijet.v12i01.6032

Sun, J., Chen, Y.-J., \& Wu, Y.-Z. (2018). Application and evaluation of problembased learning in undergraduate clinical education in 2014-2018. MedEdPublish, 7(4). doi: 10.15694/mep.2018.0000228.1

Turner, K. H., Jolls, T., Hagerman, M. S., O’Byrne, W., Hicks, T., Eisenstock, B., \& Pytash, K. E. (2017). Developing Digital and Media Literacies in Children and Adolescents. Pediatrics, 140, S122-S126. doi: 10.1542/peds.2016-1758P

Turner, S., \& Leydon, J. (2012). Improving geographic literacy among first-year undergraduate students: Testing the effectiveness of online quizzes. Journal of Geography, 111(2), 54-66. doi: 10.1080/00221341.2011.583263

Ye, L. (2015). User review: "Moodle in medical education". Retrieved from https: //www.trustradius.com/reviews/moodle-2015-09-18-18-08-29 